\title{
Fire Effects on the Cheatgrass Seed Bank Pathogen Pyrenophora semeniperda
}

\author{
Julie Beckstead, ${ }^{1}$ Laura E. Street, ${ }^{2}$ Susan E. Meyer, ${ }^{3}$ and Phil S. Allen ${ }^{4}$
}

Authors are ${ }^{1}$ Associate Professor and ${ }^{2}$ Research Assistant, Biology Department, Gonzaga University, Spokane, WA 99258, USA; ${ }^{3}$ Research Ecologist, USDA Forest Service, Rocky Mountain Research Station, Shrub Sciences Laboratory, Provo, UT 84606, USA; and ${ }^{4}$ Professor, Department of Plant and Wildlife Science, Brigham Young University, Provo, UT 84601, USA.

\begin{abstract}
The generalist fungal pathogen Pyrenophora semeniperda occurs primarily in cheatgrass (Bromus tectorum) seed banks, where it causes high mortality. We investigated the relationship between this pathogen and its cheatgrass host in the context of fire, asking whether burning would facilitate host escape from the pathogen or increase host vulnerability. We used a series of laboratory and field experiments to address the ability of host seeds and pathogen life stages to survive fire. First, we determined the thermal death point $\left(\mathrm{TDP}_{50}\right.$; temperature causing $50 \%$ mortality) of seeds and pathogen propagules at two time intervals using a muffle furnace. We then measured peak fire temperatures in prescribed burns at sites in Utah and Washington and quantified seed and fungal propagule survival using pre- and postburn seed bank sampling and inoculum bioassays. Finally, we investigated the survival of both seeds and pathogen after wildfires. We found that radiant heat generated by both prescribed and wild cheatgrass monoculture fires was generally not sufficient to kill either host seeds or pathogen propagules; most mortality was apparently due to direct consumption by flames. The 5 -min mean $\mathrm{TDP}_{50}$ was $164^{\circ} \mathrm{C}$ for pathogen propagules and $148^{\circ} \mathrm{C}$ for host seeds, indicating that the pathogen is more likely to survive fire than the seeds. Peak fire temperature at the surface in the prescribed burns averaged $130^{\circ} \mathrm{C}$. Fire directly consumed $85-98 \%$ of the viable seed bank, but prescribed burns and wildfires generally did not lead to dramatic reductions in pathogen inoculum loads. We conclude that the net effect of fire on this pathosystem is not large. Rapid postburn recovery of both host and associated pathogen populations is the predicted outcome. Postfire management of residual cheatgrass seed banks should be facilitated by the persistent presence of this seed bank pathogen.
\end{abstract}

\section{Resumen}

Pyrenophora semeniperda es un hongo patógeno generalista que se encuentra principalmente en bancos de semilla de Bromus tectorum donde causa elevada mortalidad. Se investigó la relación entre este patógeno y su huésped $B$. tectorum en el contexto del fuego, preguntando si las quemas facilitarían la evitación del patógeno por parte del huésped o si las mismas aumentarían la vulnerabilidad del huésped. Se utilizaron una serie de experimentos de laboratorio y de campo para evaluar la habilidad de sobrevivir el fuego de las semillas del huésped y de los estadíos de vida del patógeno. En primer lugar se determinó el punto térmico de mortalidad $\left(\mathrm{TDP}_{50}\right.$; la temperatura que causa $50 \%$ de mortalidad) de las semillas y los propágulos del patógeno usando dos intervalos de tiempo en una mufla. Luego se midieron las temperaturas pico del fuego en sitios de quemas prescriptas en Utah y Washington, y se cuantificó la sobrevivencia de semillas y propágulos del hongo utilizando muestreos ante-post del banco de semillas y bio-análisis del inoculo. Finalmente, se evaluó la sobrevivencia de semillas y el patógeno luego de incendios. Se encontró que el calor radiante producido tanto por quemas prescriptas como por incendios de monocultivos de B. tectorum fueron generalmente insuficientes para matar tanto a las semillas del huésped como a los propágulos del patógeno; la mayoría de la mortalidad se produjo aparentemente por combustión directa por las llamas. El TDP 50 promedio de 5 minutos fue $164^{\circ} \mathrm{C}$ para los propágulos del patógeno y $148^{\circ} \mathrm{C}$ para las semillas del huésped, indicando que la probabilidad de sobrevivencia al fuego del patógeno es superior a la de las semillas del huésped. La temperatura pico del fuego en la superficie durante quemas controladas fue en promedio de $130^{\circ} \mathrm{C}$. El fuego consumió directamente $85-98 \%$ del banco de semillas viable, pero tanto las quemas controladas como los incendios no produjeron reducciones dramáticas en las cargas de inoculo del patógeno. Se concluye que el efecto neto del fuego sobre este sistema huésped-patógeno no es grande. Una rápida recuperación post fuego tanto del huésped como del patógeno es el resultado esperado. El manejo post-fuego de los bancos de semilla residuales de B. tectorum debería facilitarse por la presencia persistente de este patógeno de los bancos de semilla.

Key Words: biological invasion, Bromus tectorum, natural enemies, plant-microbial interactions, thermal death point

\section{INTRODUCTION}

Research was funded in part by the Joint Fire Sciences Program (JFSP-2007-1-3-10; J.B., S.E.M., P.S.A.), the CSREES NRI Biology of Weedy and Invasive Species Program (2008-3532018677; J.B., S.E.M., P.S.A.), Gonzaga Science Research Program (J.B.), and a grant from the Northeast Chapter of the Washington Native Plant Society (L.E.S.).

Correspondence: Julie Beckstead, Gonzaga University, 502 E. Boone Ave., Spokane, WA 99258, USA. Email: beckstead@gonzaga.edu

Manuscript received 3 April 2010; manuscript accepted 6 December 2010
The cheatgrass (Bromus tectorum L.) invasion of vast areas of the Intermountain West is uniquely intertwined with fire. Cheatgrass has increased the frequency and size of wildfires, and these fires have in turn allowed cheatgrass to expand its dominance (Whisenant 1990; D'Antonio and Vitousek 1992; Rotenberry and Knick 1997; Chambers et al. 2007). Cheatgrass 
typically completes its life cycle as a winter annual. It produces highly flammable standing dead biomass in early summer following seed production, greatly increasing the likelihood of subsequent fire (Blank et al. 2006). Following burning, these wildlands often persist as cheatgrass-dominated areas, threatening the existence of many native plants and animals (Baker 2006; Humple and Holmes 2006; Keeley 2006; Larrucea and Brussard 2008). Even prescribed shrubland burns that aim to increase forage for livestock often result in an expansion in annual grass invasion, especially on more arid sites in the shrub steppe (Keeley 2006).

A key component of the cheatgrass-fire cycle is the fact that a fraction of the cheatgrass seed bank can survive fire (Young et al. 1976; Humphrey and Schupp 2001), thus allowing for its recovery following fire and its eventual domination of burned sites. Several factors can influence the number of cheatgrass seeds surviving a fire. Seed mortality is greatest with fires that burn while seeds are still attached to the plant, especially just before seed shatter in the summer (Brooks 2002). Higher seed mortality has also been reported for fires that burn at higher temperatures (Brooks 2002), either because of an exceptionally high density of standing dead biomass (Humphrey and Schupp 2001) or because of the presence of woody plants (Brooks 2002). Although most factors influencing the number of cheatgrass seeds surviving fires are abiotic (as listed above), biotic factors may also affect cheatgrass ability to recover following fire.

Cheatgrass-associated fire can potentially have profound effects on the soil microbial community. This may be important for understanding the cheatgrass-fire cycle because changes in plant-microbe interactions, both positive and negative, may influence native species recovery following fire. If burning reduces plant-suppressive microbes or pathogens that provide biotic resistance to cheatgrass or reduces beneficial mycorrhizae that facilitate native species establishment, then the postfire period can provide a window that favors cheatgrass expansion over native species establishment. The positive plant-microbe interactions in cheatgrass-invaded shrub steppe, specifically those involving mycorrhizae, have been examined by Rowe et al. (2007). The effects of fire on negative plant-microbe interactions in the shrub steppe remain largely unexplored. However, Kinter et al. (2007) found that rush skeletonweed (Chondrilla juncea) seeds had higher emergence in field-burned cheatgrass-invaded soils than in unburned soils, suggesting that perhaps soil organisms with a negative impact on rush skeletonweed may themselves be negatively impacted by fire. The soil microbes in the Kinter et al. (2007) study were not identified.

An important soil microbial organism of cheatgrass-invaded sites is the ascomycete seed bank pathogen Pyrenophora semeniperda (Brittlebank and Adam) Shoemaker (anamorph Drechslera campanulata [Lév.] B. Sutton). Seed infection is usually initiated by asexually produced spores (conidia) that germinate on the surface, penetrate the coverings, and then ramify as mycelium inside the seed (Beckstead et al. 2007). As the seed is consumed, the fungus initiates sporulation by producing elongate black stromata (i.e., sporocarps) that protrude through the seed coverings. These stromata then produce another generation of conidial spores that are released into the seed bank. Pyrenophora semeniperda frequently kills large numbers of cheatgrass seeds in field seed banks. Meyer et al. (2007) obtained densities of field-killed cheatgrass seeds with distinctive $P$. semeniperda stromata as high as 20000 seeds $\cdot \mathrm{m}^{-2}$ at cold desert sites in Utah and Idaho. Pyrenophora semeniperda usually has greater impacts on cheatgrass seed banks at drier sites, where the secondarily dormant seeds in the spring seed bank that are its primary host are likely to be present in higher densities (Beckstead et al. 2007). Soil seed banks dominated by cheatgrass maintain much higher inoculum levels of this generalist seed pathogen than native grass seed banks (Beckstead et al. 2010).

The primary question addressed in our study is how fire impacts survival of $P$. semeniperda and seeds of its cheatgrass host. If fire completely destroys the pathogen, then cheatgrass seeds surviving the fire would be able to establish free of this natural enemy. Conversely, if the pathogen has high postburn survival, then cheatgrass recovery from the seed bank could be negatively impacted. We investigated this question and these hypotheses in a series of laboratory and field studies. First, we quantified the thermal death point (temperature at which $50 \%$ of the individuals experience death) for three life stages of $P$. semeniperda (i.e., conidia, mycelium, and stromata) and for cheatgrass seeds. Second, we measured the temperature of prescribed cheatgrass fires in the field and compared field temperatures with the thermal death points. Third, we determined the ability of $P$. semeniperda propagules and cheatgrass seeds to survive both prescribed fires and natural wildfires.

\section{METHODS}

\section{Thermal Death Point Determination}

To determine the thermal death point $\left(\mathrm{TDP}_{50}\right.$; temperature causing $50 \%$ mortality) for cheatgrass seeds and for three life stages of the pathogen, we subjected them to a range of temperatures in a muffle furnace $\left(20^{\circ} \mathrm{C}\right.$ [control], $65^{\circ} \mathrm{C}, 100^{\circ} \mathrm{C}$, $125^{\circ} \mathrm{C}, 150^{\circ} \mathrm{C}, 200^{\circ} \mathrm{C}$, and $300^{\circ} \mathrm{C}$ ) for 5 or $15 \mathrm{~min}$ (to simulate fast- vs. slow-burning fires), and performed subsequent survivability assessment. First, to obtain the three life stages of the pathogen, we used conidial inoculum obtained from a $P$. semeniperda isolate from Tenmile Creek, Box Elder County, Utah (for inoculum production methods, see Beckstead et al. 2010). We inoculated groups of 15 healthy, viable cheatgrass seeds with $0.001 \mathrm{~g}$ of dry conidial inoculum by placing seeds and inoculum together in glass vials $(4 \mathrm{~mL})$ and shaking vigorously for $1 \mathrm{~min}$ using a handheld shaker. For the conidial stage, inoculated seeds were placed immediately into the heat treatment. To produce the mycelial and stromatal life stages, inoculated seeds were incubated for 4 and $14 \mathrm{~d}$, respectively, in individual Petri dishes $(100 \times 15 \mathrm{~mm})$ on moist germination blotters (Anchor Paper, St. Paul, MN) in a dark $20^{\circ} \mathrm{C}$ incubator. The seeds with mycelium or stromata were then allowed to air-dry prior to heat treatment. Fifteen replicate seeds in individual Petri dishes for each fungal stage treatment (uninoculated, with conidia, with mycelium, and with stromata) were subjected to each heat treatment.

To assess pathogen survival following the heat treatment, an uninfected host seed from the same seed collection was placed on each side of the inoculated, heat-treated seed as a "bait" for the pathogen. The dishes were incubated at $20^{\circ} \mathrm{C}$ in the dark 
for $4 \mathrm{wk}$ and scored for development of stromata on at least one bait seed, indicating survival of the pathogen to infection. For the seed survival assessment, uninoculated, nondormant heat-treated seeds were incubated as described above and scored for germination.

The effect of temperature treatment on survival of pathogen life stages and cheatgrass seeds was analyzed using logistic regression (LOGIT; JMP, Version 8.0.1, SAS Institute Inc., Cary, NC). Model optimal predictability was determined by Receiver Operating Characteristic curve area and was satisfactory for each analysis (DeLong et al. 1988). Inverse prediction set at $50 \%$ was used to calculate $\mathrm{TDP}_{50}$. This experiment included 15 replicated seeds for each of the pathogen life stages and cheatgrass seeds subjected to each of seven heat treatments at two time intervals for a total of 840 experimental units.

\section{Prescribed Burn Studies}

We utilized sites at Whiterocks in Skull Valley, Utah (lat $40^{\circ} 32^{\prime} \mathrm{N}$, long $112^{\circ} 77^{\prime} \mathrm{W}, 1450-\mathrm{m}$ elevation), and at Haven Flats on the Hanford Reach National Monument in Washington (lat $46^{\circ} 39^{\prime} \mathrm{N}$, long $119^{\circ} 40^{\prime} \mathrm{W}, 96-\mathrm{m}$ elevation) for prescribed burn studies. These studies combined evaluation of peak fire temperatures using pyrometers, a bioassay technique for assessment of inoculum loads of $P$. semeniperda, and direct examination of preburn and postburn seed banks (Beckstead et al. 2010). The design included 20 burned plots $\left(0.10 \mathrm{~m}^{2}\right)$ at each site. Each plot was sampled before and after burning for the inoculum load and seed bank studies; peak fire temperatures were measured on each plot during the burn.

The prescribed burns were applied differently at the two sites, but both took place in near-monocultures of cheatgrass ( $>85 \%$ cover). At the Haven Flat site, the plots were burned as part of a prescribed fire $\left(743 \mathrm{~m}^{2}\right)$ carried out in conjunction with associated field inoculation studies (P. Allen, unpublished data). The fire crew used a backing-fire technique to burn into the wind, resulting in a low rate of spread (eight chains per hour). Preburn sampling took place on 19 April 2008, the burn took place on 8 June 2008, and postburn sampling took place on 12 June 2008 . The $200.10-\mathrm{m}^{2}$ sampling plots were randomly chosen along five randomly chosen transects; plots sampled were a minimum of $2 \mathrm{~m}$ apart.

At Whiterocks, we were unable to carry out our large-scale prescribed burn in a timely manner. Instead, individual plots were burned using a burn-barrel technique (Korfmacher et al. 2003), which is appropriate for field studies where precise knowledge of timing and magnitude of temperature changes are not needed. We utilized a steel burn-barrel $1 \mathrm{~m}$ in diameter, which enclosed the sampling plot $\left(0.10 \mathrm{~m}^{2}\right)$ with at least a 20 $\mathrm{cm}$ buffer from the edge of the barrel and which included slots around the bottom to permit air intake during the burn. Conditions during the burn were hot, windy, and dry, resulting in very rapid fuel consumption after ignition within each barrel placement, with a flame duration of $<30 \mathrm{~s}$. The preburn samples were taken on 20 May 2008, the burn took place on 8 July 2008, and the postburn samples were taken on 8 July 2008. The $1-\mathrm{m}$ burn-barrel plots were laid out at $1.5 \mathrm{~m}$ between-plot intervals along two transects spaced $2 \mathrm{~m}$ apart.

Peak Fire Temperature Measurement. At the center of each of 20 sampling plots $\left(0.10 \mathrm{~m}^{2}\right)$ at a given site, we installed pyrometers at four vertical positions to measure relative peak fire temperature: $5 \mathrm{~cm}$ above the soil surface, at the soil surface, and at $1 \mathrm{~cm}$ and at $3 \mathrm{~cm}$ below the soil surface. Pyrometers were constructed using industrial temperature-indicating lacquer paints (Tempilaq, Tempil, Inc., South Plainfield, NJ) applied to thin copper oval tags $(90 \mathrm{~mm} \times 19 \mathrm{~mm} \times 0.125 \mathrm{~mm}$; National Band and Tag Co., Newport, KY) using methods similar to those of Wally et al. (2006). The tags were painted with eight Tempilaq paints melting at $52^{\circ} \mathrm{C}, 56^{\circ} \mathrm{C}, 79^{\circ} \mathrm{C}, 93^{\circ} \mathrm{C}$, $121^{\circ} \mathrm{C}, 177^{\circ} \mathrm{C}, 232^{\circ} \mathrm{C}$, and $288^{\circ} \mathrm{C}$, painted in $10-\mathrm{mm}$ streaks with $5 \mathrm{~mm}$ between streaks. The temperatures selected encompass the expected range of cheatgrass-associated fires and mirror those measured by Brooks (2002). After drying, the painted surface was covered with another copper tag and secured with wire through the tag eyelet and a staple. Pyrometers were exhumed on the same date that inoculum bioassay samples were taken and evaluated visually to estimate peak burn temperature.

We analyzed the peak fire temperature experiment as a mixed-model analysis of variance (ANOVA) with block nested within site as the random effect (Proc Mixed; SAS Version 8.1, SAS Institute Inc., Cary, NC). Site and pyrometer position were considered fixed effects. The response variable (peak fire temperature) was transformed to improve homogeneity of variance. This experiment included 20 replicated plots at each of four pyrometer positions at each of two field sites for a total of 160 experimental units.

Pathogen Inoculum Bioassay. The two inoculum bioassay sample points (i.e., pre- and postburn) in each plot were consistently located relative to pyrometer placement. We took samples by pounding a steel ring $(10 \mathrm{~cm}$ in diameter and $2.5 \mathrm{~cm}$ deep) into the soil until it was flush with the surface. A mason's trowel was then used to lift the ring with its surface litter and underlying soil layer intact (i.e., an intact sample of the seed zone). Twenty ring samples, one from each sampling point, were then placed in Petri dishes $(15 \times 100 \mathrm{~mm})$, bound with rubber bands, and transported to the laboratory. This procedure was carried out both before and after burning for a total of 40 ring samples from each site.

Inoculum bioassays were conducted by planting dormant cheatgrass seeds into the seed-zone rings and monitoring $P$. semeniperda-caused disease. Within 3 wk of field collection, each seed-zone ring was planted with 25 surface-sterilized and safranin-dyed dormant cheatgrass seeds (dyed to distinguish them from in situ seeds; for methods, see Beckstead et al. 2010). Bioassay rings were incubated for 4 wk at $20^{\circ} \mathrm{C}$ without lights; rings were randomized weekly and watered as needed. Coleoptiles of any emerged seedlings were kept clipped to 2$5 \mathrm{~cm}$. On day 28, all safranin-dyed seeds were exhumed and examined for germination and for presence of disease $(P$. semeniperda stromata). Seeds were classified as germinated without stromata, germinated with stromata, ungerminated without stromata, and ungerminated with stromata. All seeds that developed stromata, whether they germinated or not, were presumed to have been infected by the pathogen (Beckstead et al. 2007). All ungerminated seeds lacking fungal stromata were checked for viability using a cut test (Ooi et al. 2004). There was little or no loss of viability due to causes other than $P$. semeniperda. 
We analyzed the inoculum bioassay experiment as a mixedmodel ANOVA with block nested within site as the random effect in SAS Proc Mixed as described earlier. Site and burn treatment were fixed effects. The response variable (proportion of seeds infected) was transformed to improve homogeneity of variance. This experiment contained 20 replicated fieldcollected seed-zone sample (each planted with 25 seeds) for each of the burn treatments (pre- and postburn) at each of two study sites for a total of 80 experimental units.

Seed Bank Quantification. We also monitored the effects of the prescribed burn treatments described earlier on cheatgrass seed banks. Pre- and postburn seed bank samples were collected from the same plots on the same dates as the bioassay ring samples. Seed bank samples were collected using a steel can $6 \mathrm{~cm}$ in diameter and $4 \mathrm{~cm}$ deep that was inverted and pressed into the soil until flush with the soil surface and then lifted out with a mason trowel, and its contents emptied into a labeled paper sack. Samples were air-dried, screened, and hand processed to remove all apparently viable and field-killed cheatgrass seeds (for methods, see Beckstead et al. 2010). Apparently viable seeds were incubated for $4 \mathrm{wk}$ at $20^{\circ} \mathrm{C}$ and scored as germinated, viable but dormant, killed in incubation by the pathogen, or nonviable/unfilled. From this incubation test, we determined the following response variables: viable seed density (i.e., living, free of disease, and the sum of germinated and dormant seeds), field-killed seed density (i.e., recently killed by $P$. semeniperda in the field and exhibiting stromata), and incubation-killed seeds (i.e., seeds obtained from field that were preinfected with $P$. semeniperda and that developed disease signs in incubation).

For Whiterocks, we included a third sample data set in the seed bank analysis. These samples were taken from a closely adjacent area (within $50 \mathrm{~m}$ of the burn study) as part of a different study. Samples were taken from 20 blocks in an unburned area on 27 August 2008 and processed and evaluated as described above. The reason for including this third data set was to obtain an estimate of seed survival after burning. Because initial sampling on the burn plots took place before seed dispersal but both burning and postburn sampling were delayed until after seed dispersal, sampling from an adjacent unburned area was necessary to obtain an estimate of seed rain prior to the burn. Field-killed seed densities were expected to be the same for preburn and unburned plots, as these are not likely to change during summer; the only variable expected to change between preburn (and pre-seed-dispersal) plots and unburned plots was viable seed density.

We had a similar problem estimating seed survival after burning at Haven Flats, but we did not have a seed bank data set from an unburned area for comparison purposes. Instead, we used a data set for cheatgrass density on burned versus unburned plots obtained as part of an adjacent field inoculation study ( $\mathrm{P}$. Allen, unpublished data) to indirectly estimate seed survival after burning. The difference in plant density on burned and unburned plots was assumed to be directly related to the variable of interest, namely, the difference in seed density with and without burning. These data were obtained the spring following the same prescribed burn described above for Haven Flats. Fifteen $0.10-\mathrm{m}^{2}$ uninoculated control plots from adjacent unburned and burned areas at the Haven Flats site were randomly chosen. Each of these plots had received approximately 250 supplemental seeds the previous fall (i.e., postburn). Although these seed additions complicate the purpose of the present study, we were still able to detect the relative effect of prescribed burning on seed survival, as indicated by postburn plant density. Both burned and unburned plots received the same seed additions, and these additions were not sufficient to swamp out the effect of burn treatment on the seed bank. To estimate seed survival, density of individual plants was obtained by hand counting in the field, when cheatgrass was at the early seed production stage. We also counted individual tillers, and biomass per plot was measured by collecting aboveground plant shoots, drying them at $60^{\circ} \mathrm{C}$ for $72 \mathrm{~h}$, and weighing. From these measures, we calculated plant density, tillers per plant, biomass per plant, and biomass per plot for each of the 30 plots.

The analyses for the effect of prescribed burning on the seed bank were different for Whiterocks and Haven Flats. We chose to exclude the seed bank data from Haven Flats because of problems with sampling dates described above. The Whiterocks seed bank data were analyzed using ANOVA in SAS for a completely randomized design with burn treatment (preburn, postburn, and unburned) as the fixed effect. The experiment could not be considered blocked because the unburned treatment was not included in the original block design. Response variables were viable seed density, field-killed seed density, and density of incubation-killed seeds as described earlier; these were $\log$ transformed prior to analysis. We included 20 replications in each of the three burn treatments for a total of 60 experimental units.

For the Haven Flats site, the effect of the prescribed burn treatment on plant density, tillers per plant, biomass per plant, and biomass per plot were analyzed using a completely randomized ANOVA design in SAS as described above. The response variables were log transformed to improve homogeneity of variance prior to analysis. We included 15 replicates for each of the two burn treatments for a total of 30 experimental units.

\section{Wildfire Seed Bank Studies}

We took advantage of natural August 2007 burns in cheatgrass monocultures on West Mountain in northern Utah (lat $40^{\circ} 14^{\prime} \mathrm{N}$, long $111^{\circ} 81^{\prime} \mathrm{W}, 1390-\mathrm{m}$ elevation) and at Rattlesnake Mountain on the Hanford Reach National Monument in Washington (lat $46^{\circ} 23^{\prime} \mathrm{N}$, long $83^{\circ} 30^{\prime} \mathrm{W}, 732$-m elevation) to evaluate the effect of wildfire on both cheatgrass seed banks and $P$. semeniperda abundance. Sampling took place within 1 mo of each burn and prior to any cheatgrass autumn germination. On the West Mountain burn, we selected a site where an elongate island of unburned cheatgrass remained in the center of a burned area. This island apparently remained unburned because of wind shifts during the fire and not because of any obvious topographical or soil difference. At $5-\mathrm{m}$ intervals along the boundary of the unburned area, we sampled at a distance of $2 \mathrm{~m}$ from the edge of the burn on both the burned and the unburned sides. Ten seed bank samples each from burned and unburned areas were obtained. Seed bank samples were taken as described earlier. A similar protocol was followed at the Rattlesnake Mountain site, 
except the burned and unburned areas were located on opposite sides of a dirt road, 20 samples each from burned and unburned areas were obtained, and a small hand shovel was used instead of a can (although area sampled was roughly the same). Soil seed bank samples were processed and evaluated as described above.

Data sets from the two sites were combined for ANOVA for a randomized design. We used SAS Proc GLM because of unequal replication between sites. Fixed main effects specified in the ANOVA were site (West Mountain vs. Rattlesnake Mountain) and burn treatment (burned vs. unburned). The response variables were density of viable seeds, density of fieldkilled seeds, and density of incubation-killed seeds; these were log transformed for analysis to increase homogeneity of variance. This experiment included either 10 (West Mountain) or 20 (Rattlesnake Mountain) replicated field-collected seed bank samples for each of the burn treatments for a total of 60 experimental units.

\section{RESULTS}

\section{Thermal Death Point Determination}

The ability of the seed pathogen $P$. semeniperda to survive high temperature and subsequently infect adjacent host seeds decreased with increasing temperature and varied among life stages after the 5-min heat treatment (Fig. 1a; temperature main effect: $\chi^{2}=225.27, \mathrm{df}=1, P<0.0001$; life stage main effect: $\left.\chi^{2}=6.71, \mathrm{df}=2, P=0.03\right)$. The conidial stage experienced $50 \%$ mortality at a lower temperature than the mycelial and stromatal stages (conidial stage $\mathrm{TDP}_{50}=141.36^{\circ} \mathrm{C}$, mycelial stage $\mathrm{TDP}_{50}=174.57^{\circ} \mathrm{C}$, stromatal stage $\mathrm{TDP}_{50}=178.34^{\circ} \mathrm{C}$ ).

After the 15 -min heat treatment, pathogen survival was again significantly affected by temperature, but the difference between life stages was only marginally significant (Fig. 1b; temperature main effect: $\chi^{2}=227.87 ; \mathrm{df}=1 ; P<0.0001$; life stage main effect: $\left.\chi^{2}=5.52 ; \mathrm{df}=2 ; P=0.06\right)$. Mean thermal death point across life stages was $14 \%$ lower for the longerduration heat treatment $\left(15-\mathrm{min}\right.$ overall $\mathrm{TDP}_{50}=141.60^{\circ} \mathrm{C}$, and 5 -min overall $\mathrm{TDP}_{50}=164.21^{\circ} \mathrm{C}$ ), indicating lower survival after a longer heat treatment period.

The ability of cheatgrass seeds to survive high temperature also decreased with increasing temperature and showed a similar pattern after 5 - and 15 -min heat treatment durations (Fig. 1c; 5-min treatment: $\chi^{2}=126.32, \mathrm{df}=1, P<0.0001 ; 15$ min treatment: $\left.\chi^{2}=129.78, \mathrm{df}=1, P<0.0001\right)$. The $\mathrm{TDP}_{50}$ for cheatgrass seeds was $10 \%$ lower than the mean $\mathrm{TDP}_{50}$ for the pathogen at each of the two treatment durations, indicating that the seeds would be killed at a lower temperature than the pathogen (for seeds: $\mathrm{TDP}_{50}$ at 5 -min interval $=147.64^{\circ} \mathrm{C}$, and $\mathrm{TDP}_{50}$ at $15-\mathrm{min}$ interval $=127.33^{\circ} \mathrm{C}$ ).

\section{Prescribed Burn Studies}

Peak Fire Temperature Measurement. Prescribed burn peak fire temperature varied with distance above or below the soil surface. The highest flame temperatures were measured at and above the soil surface, averaging around $144^{\circ} \mathrm{C}$, whereas fire temperatures were lower below the soil surface, averaging around $63^{\circ} \mathrm{C}$ (Fig. 2; pyrometer position main effect: $\mathrm{df}=3,152$;
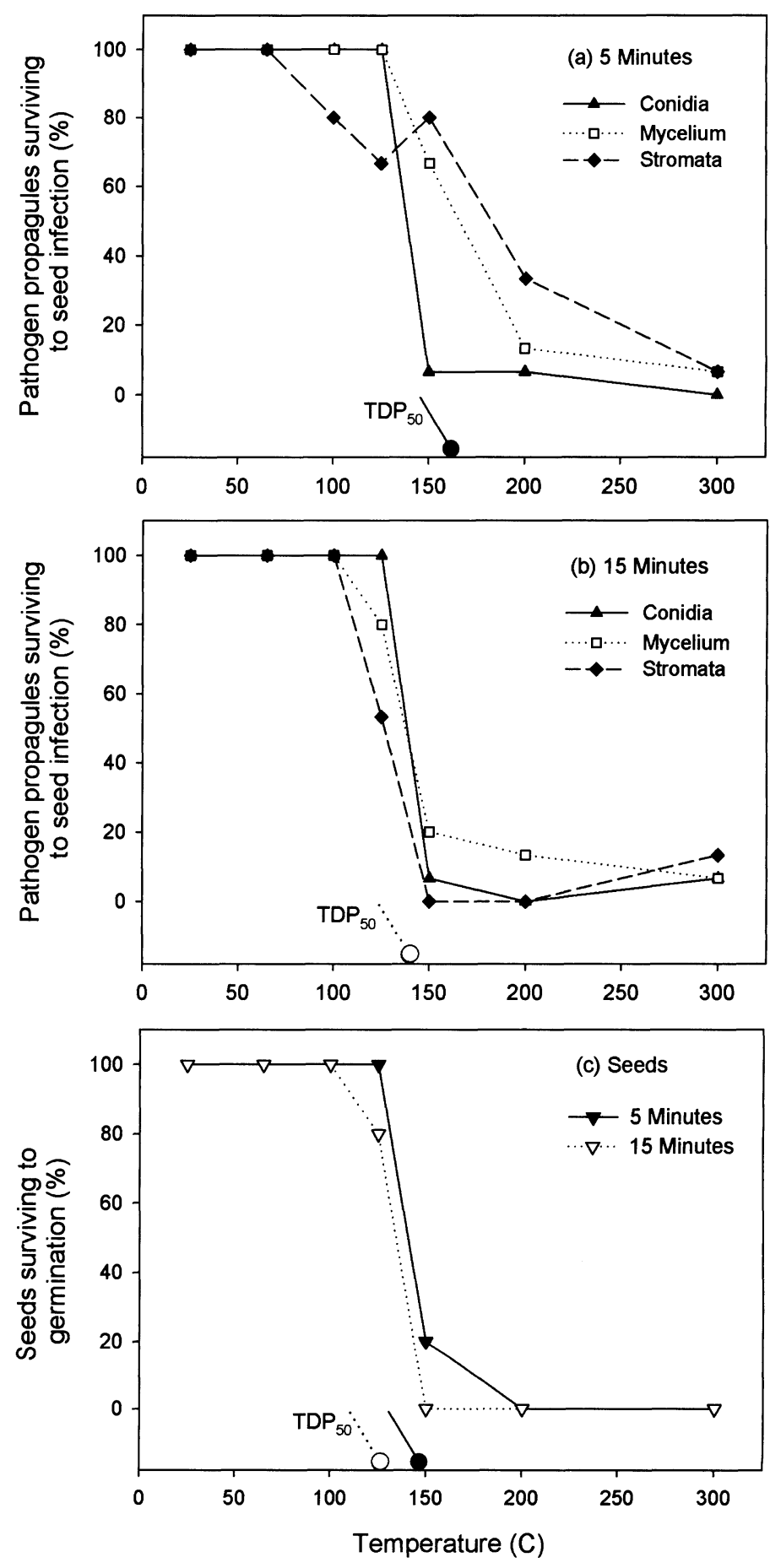

Figure 1. Thermal death curves showing the effect of radiant heat after 5- and 15-min heat treatments on survival of Pyrenophora semeniperda life stages (a, b) and cheatgrass (Bromus tectorum) seeds (c) $(n=15$ seeds). Thermal death points (TDP 50 ; temperature at which $50 \%$ of the individuals experience death) are indicated for the average of all pathogen life stages after $5 \mathrm{~min}\left(\mathrm{a}\right.$; $\left.\operatorname{TDP}_{50}=164^{\circ} \mathrm{C}\right)$, for the average of all pathogen life stages after $15 \mathrm{~min}\left(\mathbf{b} ; \operatorname{TDP}_{50}=142^{\circ} \mathrm{C}\right)$, and for cheatgrass seeds after 5 and $15 \min \left(\mathbf{c} ; \mathrm{TDP}_{50}=148^{\circ} \mathrm{C}\right.$ and $127^{\circ} \mathrm{C}$, respectively).

$\mathrm{F}=74.44 ; P<0.0001)$. There was no significant difference in overall peak fire temperature between the two sites (Fig. 2; site main effect: $\mathrm{df}=1,152 ; \mathrm{F}=1.67 ; P=0.20$ ). There was, however, a significant site $\times$ pyrometer position treatment 


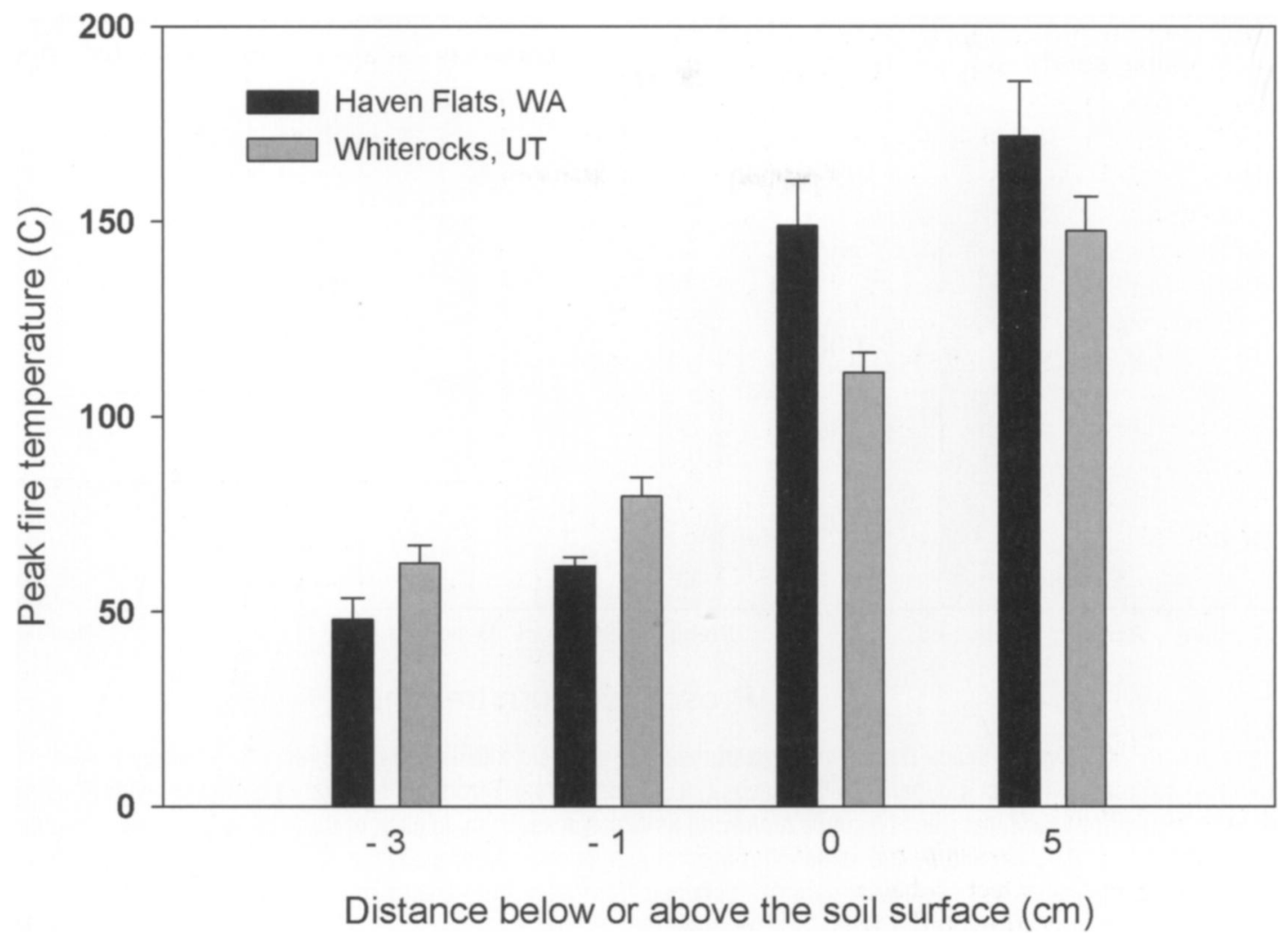

Figure 2. The peak fire temperatures measured during prescribed burns using pyrometers with temperature-indicating paints placed at positions above, at, or below the soil surface at the Haven Flats, Washington, and Whiterocks, Utah, study sites (mean +1 SE). Data represent 20 replicated pyrometers for each site $\times$ pyrometer position combination.

interaction $(\mathrm{df}=3,152 ; \mathrm{F}=5.92 ; P=0.0008)$, indicating that soil properties and/or aboveground litter were different between sites, resulting in different peak fire temperature patterns. The fire burned substantially hotter at and above the soil surface at Haven Flats, whereas subsurface temperatures during the burn were slightly higher at Whiterocks.

Pathogen Inoculum Load Bioassay. Laboratory experiments with field-collected seed-zone samples from preburn and postburn plots at the two sites demonstrated differences between sites in the fraction of planted cheatgrass seeds infected by $P$. semeniperda. Mean disease incidence was $25 \%$ for Whiterocks Utah but only $13 \%$ for Haven Flats (site main effect: $\mathrm{df}=1,76$, $F=23.48, P<0.0001)$. Mean disease incidence did not vary significantly between burn treatments, indicating that pathogen inoculum was generally able to survive fire (burn treatment main effect: $\mathrm{df}=1,76 ; \mathrm{F}=0.14 ; P=0.71$ ). There was a significant site $\times$ burn treatment interaction, however $(\mathrm{df}=1,76 ; \mathrm{F}=10.57$; $P=0.002$ ). This interaction was significant because samples at the Haven Flats site demonstrated a decrease in seed infection following the burn (preburn infection of $18 \%$ and postburn infection of $8 \%$ ), whereas samples from the Whiterocks site actually showed an increase in postburn seed infection (preburn infection of $19 \%$ and postburn infection of $32 \%$ ).

Seed Bank Quantification. The prescribed burn treatment at the Whiterocks site had a very large impact on viable seed density in the cheatgrass seed bank (Fig. 3a; df $=2,57$; $\mathrm{F}=30.90 ; P<0.0001)$. Fire drastically reduced the cheatgrass seed bank; only an estimated $12 \%$ survived the burn (mean of
30400 seeds $\cdot \mathrm{m}^{-2}$ in the unburned plots vs. 3600 seeds $\cdot \mathrm{m}^{-2}$ in the postburn plots). The majority $(97 \%)$ of the seed bank present at the time of the burn was from current-year seed production, as the carryover present prior to both seed shatter and burning was only 800 seeds $\cdot \mathrm{m}^{-2}$. Fire had a similar impact on field-killed seed density (Fig. 3b; $\mathrm{df}=2,57$; $\mathrm{F}=15.68 ; \quad P<0.0001)$. Postburn density was only 1400 field-killed seeds $\cdot \mathrm{m}^{-2}$ compared to 7650 and 8940 killed seeds $\cdot \mathrm{m}^{-2}$ in the preburned and unburned plots, respectively, or an average burn survival of $17 \%$ (Fig. $3 \mathrm{~b}$ ). As expected, field-killed seed density did not differ significantly between the unburned area and the preburn plots, evidence that these plots represented two sets of samples from essentially the same population (Fig. $3 \mathrm{~b}$ ). In contrast to viable and field-killed seed density, the density of seeds killed in incubation did not differ significantly among burn treatments (Fig. $3 \mathrm{c} ; \mathrm{df}=2,57$; $\mathrm{F}=0.82 ; P=0.44)$, and for samples from the same plots, the means were very similar (preburn 850 vs. postburn 810 seeds $\cdot \mathrm{m}^{-2}$ ). The density was somewhat higher in the unburned plots, but because of high variance, this difference was not significant. Incubation-killed seeds are seeds that were already infected by the pathogen at the time of seed bank drying in late spring, so that the ability of the pathogen to grow out of these seeds following burning indicates that the mycelial stage inside the host seed was able to survive the fire.

Prescribed burning at the Haven Flats site also had a large impact on several cheatgrass density and biomass measures taken the following spring. Fire reduced plant density by $96 \%$ (Fig. $4 \mathrm{a} ; \mathrm{df}=1,21 ; \mathrm{F}=372.18 ; P<0.0001$ ). However, the 

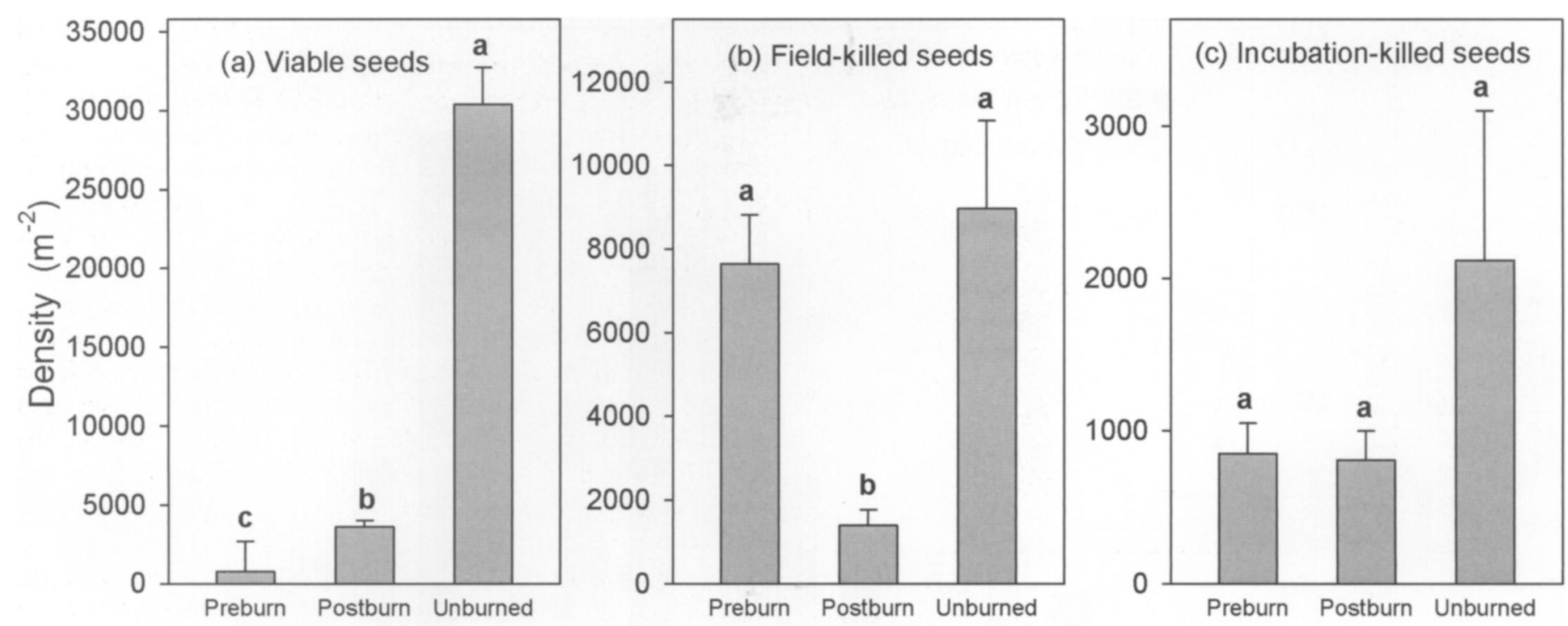

Prescribed burn treatment

Figure 3. Seed bank density of (a) viable seeds (i.e., living, free of disease), (b) field-killed seeds (i.e., recently killed by Pyrenophora semeniperda in the field and exhibiting stromata), and (c) incubation-killed seeds (i.e., seeds obtained from field that are preinfected with $P$. semeniperda and that develop disease signs in incubation) for cheatgrass (Bromus tectorum) at Whiterocks, Utah, in each of three burn treatments (preburn, postburn, and adjacent unburned; mean $+1 \mathrm{SE}$ ). Bars capped by the same letter are not significantly different at the $P=0.05$ level according to a Duncan multiple range test. Data represent 20 replicated soil seed bank samples obtained from each burn treatment.

plants on burned plots had three times as many tillers as plants on unburned plots (Fig. $4 \mathrm{~b} ; \mathrm{df}=1,21 ; \mathrm{F}=114.61 ; P<0.0001$ ). Although density varied greatly between burn treatments, biomass per plot did not differ significantly (Fig. 4c; $\mathrm{df}=1,28 ; \mathrm{F}=1.11 ; P=0.30)$. Individual plants on burned plots were 20 times larger on average than plants on unburned plots (Fig. 4d; $\mathrm{df}=1,21 ; \mathrm{F}=311.06 ; P<0.0001$ ).

\section{Wildfire Seed Bank Studies}

In the wildfire seed bank studies, density of viable cheatgrass seeds differed between sites and as a function of wildfire (Fig. 5a; Table 1). The West Mountain, Utah, site had 1.4 times as many viable seeds per square meter as the Rattlesnake Mountain, Washington, site, though both sites had viable seed densities of over $10000 \cdot \mathrm{m}^{-2}$ in the unburned treatment. Wildfire dramatically reduced viable seed density at both sites; the Rattlesnake Mountain site had a $98 \%$ reduction, while the West Mountain site had an $85 \%$ reduction. This difference in seed survival ( $2 \%$ vs. $15 \%$ ) was reflected in a significant site $\times$ burn interaction (Table 1).

The potential inoculum load for $P$. semeniperda measured as the density of field-killed cheatgrass seeds with stromata varied significantly between sites; the West Mountain site had a fieldkilled seed density 20 times higher than the Rattlesnake Mountain site (Fig. 5b; Table 1). Overall, fire reduced the density of field-killed seeds from 890 to 680 killed seeds $\cdot \mathrm{m}^{-2}$, a difference that was only marginally significant. The ability of the pathogen to survive fire at the mycelial stage, internally in seeds, was once again indicated by the lack of any significant difference between burn treatments in density of incubationkilled seeds. The West Mountain site had much higher densities of incubation-killed seeds overall (1 190 vs. $\left.130 \cdot \mathrm{m}^{-2}\right)$, a result similar to the result for field-killed seeds (Fig. 5c).

\section{DISCUSSION}

The hypothesis that fire creates a window for cheatgrass expansion by eliminating the natural enemy $P$. semeniperda was not supported. We also found that fires in cheatgrass monocultures destroyed most of the current-year seed production through direct flame consumption but that fires rarely
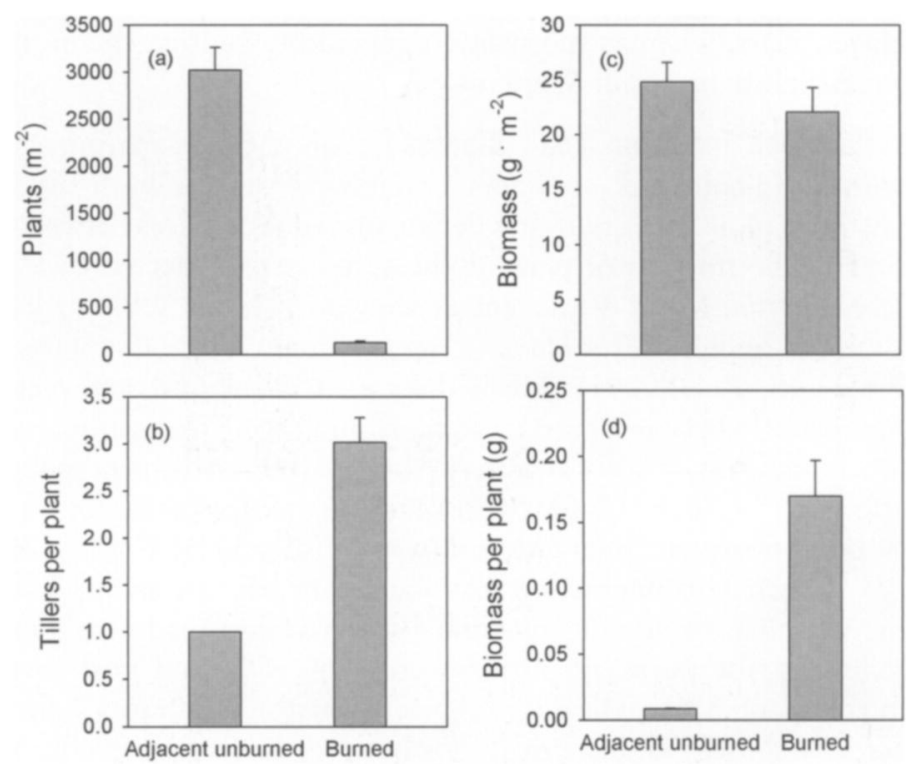

Prescribed burn treatment

Figure 4. Effects of a prescribed burn at Haven Flats, Washington, on cheatgrass (Bromus tectorum): (a) density, (b) tillers per plant, (c) biomass per unit area, and (d) biomass per plant (mean $\pm \mathrm{SE}$ ). Data represent means from 15 plots per burn treatment sampled in late spring following prescribed fire the previous summer. 

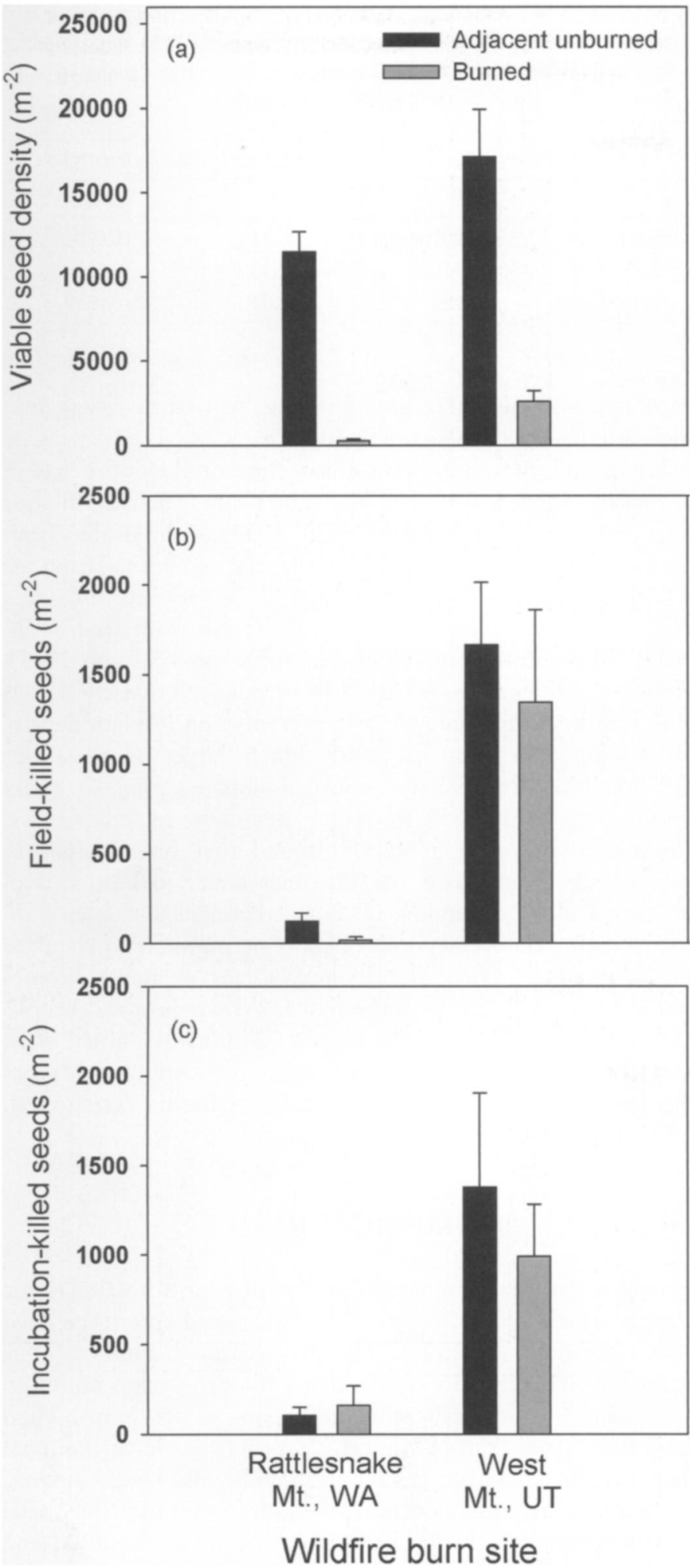

Figure 5. Effects of wildfires at Rattlesnake Mountain, Washington, and West Mountain, Utah, on cheatgrass (Bromus tectorum) seed bank (a) viable seed density (i.e., living, free of disease), (b) field-killed seed density (i.e., recently killed by Pyrenophora semeniperda in the field and exhibiting stromata), and (c) incubation-killed seed density (i.e., seeds obtained from field that are preinfected with $P$. semeniperda and that develop disease signs in incubation); mean +1 SE. Data represent 10 (West Mountain) or 20 (Rattlesnake Mountain) soil samples collected from each treatment combination. burned hot enough to kill seeds via radiant heat. In the laboratory experiment, seeds had to be exposed to temperatures greater than $150^{\circ} \mathrm{C}$ for 5 min to result in high mortality. In the prescribed burn experiments, seeds at the soil surface or above (i.e., in the litter layer) did experience temperatures around $150^{\circ} \mathrm{C}$ (duration less than $5 \mathrm{~min}$ ) and would also experience direct flame consumption. However, seeds $1 \mathrm{~cm}$ below the soil surface experienced fire temperature only less than $70^{\circ} \mathrm{C}$, not hot enough to kill seeds via radiant heat. Similarly, $P$. semeniperda inoculum on or in seeds or in the litter may be consumed directly by fire along with host seeds, but if not directly consumed, the pathogen frequently survives. Although both cheatgrass seeds and $P$. semeniperda can survive fire, they do not survive to the same degree; the pathogen exhibited higher postburn survival than cheatgrass seeds (e.g., Figs. 1 and 5).

Comparison of $\mathrm{TDP}_{50}$ for pathogen life stages with fire temperatures measured during prescribed burns explains why radiant heat during the cheatgrass burns apparently had little impact on pathogen viability. Laboratory measurements of $\mathrm{TDP}_{50}$ for the pathogen predicted that temperatures above $164^{\circ} \mathrm{C}$ for 5 min were needed for mortality, whereas predicted peak fire temperature for seed mortality was $148^{\circ} \mathrm{C}$ for $5 \mathrm{~min}$ (e.g., Fig. 1). TDP 50 was thus higher for the pathogen, indicating that hotter fires would be needed to kill the pathogen than host seeds. The mycelial and stromatal stages of the fungus survived high temperatures better than the conidial stage. Field-measured peak aboveground fire temperatures ranged from about $120^{\circ} \mathrm{C}$ to $170^{\circ} \mathrm{C}$ (e.g., Fig. 2), suggesting that particularly the hotter fire at Haven Flats could have killed some seeds and pathogen propagules via radiant heat. These temperatures are slightly higher than those reported for annual grassland burns in the arid western Mojave Desert (Brooks 2002) but similar to those reported for grassland fires of the Canadian prairies (Bailey and Anderson 1980). However, it is likely that peak temperatures during cheatgrass fires usually last only a few seconds and only rarely as long as $5 \mathrm{~min}$ (Stinson and Wright 1969; M. Brooks, personal communication, February 2010). This suggests that $\mathrm{TDP}_{50}$ values for peak temperatures at the short durations experienced in field burns would be even higher, further explaining the low mortality from radiant heat in our field studies. Our data do predict that somewhat hotter fires, as when shrublands first burn (Bailey and Anderson 1980) or when there is exceptionally heavy standing litter (Humphrey and Schupp 2001), could eliminate this pathogen and create a temporary "enemy-free" zone. However, under these hot fire conditions, our data predict that it is likely that most if not all cheatgrass seeds would be killed as well.

In general, we saw higher seed mortality than pathogen mortality as a consequence of fire, particularly when the pathogen was in the mycelial life stage within seeds. This could be partly due to the superior ability of the pathogen to survive radiant heat. It could also be related to the vertical position of healthy viable seeds versus infected or killed seeds in the seed bank. Most of the viable seeds were recently dispersed and probably located on the surface of the litter, where they would be more likely to be directly consumed by fire. In contrast, infected and killed seeds were carryover seeds that would be likely to be buried deeper in the litter or located at the interface 
Table 1. ANOVA results for the effects of site and wildfire burn treatments on seed bank components, including cheatgrass (Bromus tectorum) viable seed density (i.e., living, free of disease), field-killed seed density (i.e., recently killed by Pyrenophora semeniperda in the field and exhibiting stromata), and density of seeds killed in incubation (i.e., seeds obtained from field that are preinfected with $P$. semeniperda and that develop disease signs in incubation).

\begin{tabular}{|c|c|c|c|c|c|c|c|}
\hline \multirow[b]{2}{*}{ Source } & \multirow[b]{2}{*}{ df } & \multicolumn{2}{|c|}{ Viable seed density } & \multicolumn{2}{|c|}{ Field-killed seed density } & \multicolumn{2}{|c|}{ Incubation-killed seed density } \\
\hline & & $\mathrm{F}$ & $P$ & $\mathrm{~F}$ & $P$ & $\mathrm{~F}$ & $P$ \\
\hline Site & 1,56 & 14.21 & 0.0004 & 65.50 & 0.0001 & 35.64 & 0.0001 \\
\hline Burn & 1,56 & 86.67 & 0.0001 & 3.75 & 0.0578 & 0.13 & 0.7214 \\
\hline Site $\times$ burn & 1,56 & 7.63 & 0.0078 & 0.05 & 0.8225 & 0.04 & 0.8519 \\
\hline
\end{tabular}

with mineral soil, where they would be less likely to be consumed directly by fire and also less likely to experience lethal doses of radiant heat.

From the seed pathogen perspective, prescribed fires and wildfires did not lead to dramatic reductions in infection or inoculum loads (e.g., pathogen inoculum load bioassay results and Fig. 5, respectively); the one exception was the Haven Flats prescribed burn where surface fire temperatures were high, reducing infection by $56 \%$ (e.g., pathogen inoculum load bioassay results). At Whiterocks, there was no evidence for an inoculum decrease; mortality in the seed bioassay test was actually greater in the postburn samples. The reason for this is unknown, but it could be related to differences in the phenology of conidial production at the two sites. Cheatgrass at other sites on the Hanford Reach National Monument, where Haven Flats is located, generally have advanced phenology relative to Whiterocks because the springs are warmer and drier there (Beckstead et al. 2010). It is likely that this relative difference in phenology is present for pathogen conidial production as well. Most infection in seed bioassays is probably due to conidial inoculum. If conidial production had not yet taken place at the time of preburn sampling at Whiterocks, this could have reduced infection in the inoculum bioassay test relative to postburn levels, which in turn were not much impacted by the burn itself because of cooler surface fire temperatures.

Integrating our laboratory thermal death point measurements with the field-measured fire intensities, it is clear that annual grassland fires in our study, whether prescribed burns or wildfires, were not hot enough to eliminate $P$. semeniperda from the seed zone. Although spores have been found to be fireresistant fungal propagules primarily for mycorrhizae (Baar et al. 1999; Pattinson et al. 1999; Bruns et al. 2002), other studies support our findings of resistant mycelium embedded within plant tissues. For example, pathogenic fungi such as Phellinus weirii (Dickman and Cook 1989) and Phanerochaete raduloides (Penttilä and Kotiranta 1996) appear to persist as latent mycelium and to spread within living trees after fire. Sporocarps, such as stromata, are often thought to protect fungi during fire (Pattinson et al. 1999), and this idea was also supported by our study. In several of the studies examining fungal life stages and fire, it was found that newly dispersed fungal spores moved on to burned sites and were the primary source of fungal colonization (Wicklow 1975; Johannesson et al. 2001; Bruns et al. 2002). While this process is also likely to occur with $P$. semeniperda, it cannot explain the high level of inoculum found postburn at Whiterocks because the samples were taken immediately after burning, so that dispersal onto the site could not yet have taken place.

We found that both prescribed fires and wildfire had a dramatic impact on the cheatgrass seed bank. In our quantification of pre- and postburn viable seed densities from prescribed fires and the adjacent unburned and burned from the wildfire, only $2-17 \%$ of the seed bank survived fire (e.g., Figs. 3 and 5), values similar to those from prior studies (320\%; Young and Evans 1976; Humphrey and Schupp 2001). However, evidence from Haven Flats indicated that cheatgrass was able to compensate for a large reduction in plant density the spring following fire with much larger biomass per individual in burned versus unburned plots (e.g., Fig. 4). These findings are similar to those for a closely related species, Bromus rubens. Brooks (2002) found that biomass per $B$. rubens individual was 5 to 100 times larger in burned than unburned plots, depending on burn treatment and microhabitat, showing the tremendous phenotypic plasticity in response to resource availability. Density and biomass of annual bromes can increase or decrease in the first few years postfire (Brooks 2002). However, eventually Bromus dominates burned sites, and it does so across a wide range of community types throughout the Mojave Desert and Great Basin (Young et al. 1976; Hunter 1991).

\section{IMPLICATIONS}

The pathogen $P$. semeniperda can destroy a large fraction of the cheatgrass seed bank, up to $50 \%$ of the seeds produced each year (Meyer et al. 2007). The demonstrated ability of this pathogen to survive fire means that pathogen-caused mortality will continue unabated whether or not a site burns. High mortality from this pathogen appears to have minimal demographic consequences for its annual grass host, however. These minimal consequences result both from prolific host seed production (up to 30000 seeds $\cdot \mathrm{m}^{-2}$; Smith et al. 2008) and because rapid germination of the first seedling cohort each year virtually guarantees that numerous host seeds escape from the pathogen and establish as seedlings that produce seeds the following spring (Beckstead et al. 2007). This ensures the continued existence of both host and pathogen through time regardless of the frequency of burning. Our studies predict rapid postburn recovery of both host and associated pathogen populations after fire. Postfire management of residual cheatgrass seed banks may be facilitated by the persistent presence of this seed bank pathogen. Pathogen attack has the 
potential to reduce viable cheatgrass seed density, which will likely already be quite low following fire, to levels that could permit postburn establishment of seeded species.

\section{ACKNOWLEDGMENTS}

We thank Hanford Reach National Monument and the Bureau of Land Management Salt Lake City District for access to field study sites. Our thanks to Sandra Dooley, Trevor Davis, Kellene Bergen, Thom Stewart, Katie Temus Merrill, and Keith Merrill, whose help with planning, data collection, and fieldwork made this project possible. Thanks to Mike Gregg and the US Fish and Wildlife Fire Crew for help with the prescribed burn at Hanford Reach National Monument. Thanks to Mike Gregg and Duane Smith for the wildfire seed bank samples. Steve Hayes and David Boose gave support in data analysis. The manuscript was improved by insightful comments from the Editor and two anonymous reviewers.

\section{LITERATURE CITED}

Baar, J., T. R. Horton, A. M. Kretzer, and T. D. Bruns. 1999. Mycorrhizal colonization of Pinus muricata from resistant propagules after a standreplacing wildfire. New Phytologist 143:409-418.

Bailey, A. W., and M. L. Anderson. 1980. Fire temperatures in grass, shrub and aspen forest communities of Central Alberta. Journal of Range Management 33:37-40.

BAKER, W. L. 2006. Fire and restoration of sagebrush ecosystems. Wildlife Society Bulletin 34:177-185.

Beckstead, J., S. E. Meyer, B. M. Connolly, M. B. Huck, and L. E. Street. 2010. Cheatgrass facilitates spillover of a seed bank pathogen onto native grass species. Journal of Ecology 98:168-177.

Beckstead, J., S. E. Meyer, C. J. Molder, and C. Smith. 2007. A race for survival: can Bromus tectorum seeds escape Pyrenophora semeniperda-caused mortality by germinating quickly? Annals of Botany 99:907-914.

Blank, R. R., R. H. White, and L. H. Ziska. 2006. Combustion properties of Bromus tectorum $\mathrm{L}$.: influence of ecotype and growth under four $\mathrm{CO}^{2}$ concentrations. International Journal of Wildland Fire 15:227-236.

Brooks, M. L. 2002. Peak fire temperatures and effects on annual plants in the Mojave desert. Ecological Applications 12:1088-1102.

Bruns, T., J. Tan, M. Bidartondo, T. Szaro, and D. Redecker. 2002. Survival of Suillus pungens and Amanita francheti ectomycorrhizal genets was rare or absent after a stand-replacing wildfire. New Phytologist 155:517-523.

Chambers, J. C., B. A. Roundy, R. R. Blank, S. E. Meyer, and A. Whittaker. 2007. What makes Great Basin sagebrush ecosystems invasible by Bromus tectorum? Ecological Monographs 77:117-145.

D’Antonio, C. M., and P. M. Vitousek. 1992. Biological invasions by exotic grasses, the grass/fire cycle, and global change. Annual Review of Ecology and Systematics 23:63-87.

Delong, E., D. Delong, and D. L. Clarke-Pearson. 1988. Comparing the areas under two or more correlated receiver operating characteristic curves: a nonparametric approach. Biometrics 44:837-845.

Dickman, A., AND S. Cook. 1989. Fire and fungus in a mountain hemlock forest. Canadian Journal of Botany 67:2005-2016.

HumphreY, L. D., AND E. W. Schupp. 2001. Seed banks of Bromus tectorum-dominated communities in the Great Basin. Western North American Naturalist 61:85-92.
Humple, D. L., and A. L. Holmes. 2006. Effects of a fire on a breeding population of loggerhead shrikes in sagebrush steppe habitat. Journal of Field Ornithology 77:21-28.

Hunter, R. B. 1991. Bromus invasions on the Nevada test site: present status of $B$. rubens and $B$. tectorum with notes on their relationship to disturbance and altitude. Great Basin Naturalist 51:176-182.

Johannesson, H., R. Vasiliauskas, A. Dahlberg, R. Penttilä, and J. Stenlid. 2001. Genetic differentiation in Eurasian populations of the postfire ascomycete Daldinia loculata. Molecular Ecology 10:1665-1677.

KeELEY, J. E. 2006. Fire management impacts on invasive plants in the western United States. Conservation Biology 20:375-384.

Kinter, C. L., B. A. Mealor, N. L. Shaw, and A. L. Hild. 2007. Postfire invasion potential of rush skeletonweed (Chondrilla juncea). Rangeland Ecology \& Management 60:386-394.

Korfmacher, J. L., J. C. Chambers, R. J. Tausch, B. A. Roundy, S. E. Meyer, and S. KITCHEN. 2003. Technical note: a technique for conducting small-plot burn treatments. Journal of Range Management 56:251-254.

Larrucea, E. S., and P. F. Brussard. 2008. Shift in location of pygmy rabbit (Brachylagus idahoensis) habitat in response to changing environments. Journal of Arid Environments 72:1636-1643.

Meyer, S. E., D. Quinney, D. L. Nelson, and J. Weaver. 2007. Impact of the pathogen Pyrenophora semeniperda on Bromus tectorum seedbank dynamics in North American cold deserts. Weed Research 47:54-62.

OOI, M., T. Aulk, AND R. Whelan. 2004. Comparison of the cut and tetrazolium tests for assessing seed viability: a study using Australian native Leucopogon species. Ecological Management and Restoration 5:141-143.

Pattinson, G. S., K. A. Hammill, B. G. Sutton, and P. A. McGee. 1999. Simulated fire reduces the density of arbuscular mycorrhizal fungi at the soil surface. Mycological Research 103:491-496.

Penttilä, R., and H. Kotiranta. 1996. Short-term effects of prescribed burning on wood-rotting fungi. Silva Fennica 30:399-419.

RotenberRY, J. T., AND S. T. KNICK. 1997. Landscape characteristics of disturbed shrub steppe habitats in southwestern Idaho (U.S.A.). Landscape Ecology 12:287-297.

Rowe, H. I., C. S. Brown, and V. P. ClaAssen. 2007. Comparisons of mycorrhizal responsiveness with field soil and commercial inoculum for six native montane species and Bromus tectorum. Restoration Ecology 15:44-52.

Smith, D. C., S. E. Meyer, and V. J. Anderson. 2008. Factors affecting Bromus tectorum seed bank carryover in western Utah. Rangeland Ecology \& Management 61:430-436.

Stinson, K. J., AND H. A. WRight. 1969. Temperatures of headfires in the southern mixed prairie of Texas. Journal of Range Management 22:169-174.

Wally, A. L., E. S. Menges, and C. W. Weekley. 2006. Comparison of three devices for estimating fire temperatures in ecological studies. Applied Vegetation Science 9:97-108.

WhISENANT, S. G. 1990. Changing fire frequencies on Idaho's Snake River Plains: ecological and management implications. In: D. D. McArthur, E. M. Romney, S. 0. Smith, and P. T. Tueller [EDS.]. Proceedings, symposium on cheatgrass invasion, shrub die-off and other aspects of shrub biology and management. General Technical Report INT-276. Ogden, UT: US Dept of Agriculture Forest Service, Intermountain Research Station. p. 4-10.

WickLow, D. T. 1975. Fire as an environmental cue initiating ascomycete development in a tallgrass prairie. Mycologia 67:852-862.

Young, J. A., R. A. Evans, and R. A. Weaver. 1976. Estimating potential downy brome competition after wildfires. Journal of Range Management 29:322-325. 